\title{
Constructing Gender Identity in the Humorous Conversations of Males and Females
}

Dr. Miranda Mohamed Khamis EL-Zouka Associate Professor, English Department Faculty of Arts, Damanhour University 


\section{Introduction}

The area of humour and gender has received great attention by linguists. Humour occurs frequently in the daily conversations of both men and women, whether in mixed- or same-sex groups. Sometimes the success of the interaction process is achieved because of using humour. Humour can help speakers achieve their aims because of the positive atmosphere that exists in an ongoing conversation. Moreover, humour helps speakers, whether males or females to construct their identity and to manifest how they portray themselves to other speakers to prove that they are of equal status. The present study is an attempt in this area.

\section{Aims and Methodology of the Study}

Humour occurs in a wide range of conversations in many social contexts. In these conversations, participants interact with each other and humour occurs, so it is a collaborative conversational activity and also a spontaneous one.

The study investigates how males and females use humour in their conversations to construct their identity using the conversation analysis technique (CA). This is done by clarifying how they portray themselves 
in humorous conversations to be able to keep their positive self-image. The study also identifies the various most commonly employed linguistic devices by males and females in same- and mixed-sex humorous conversations used to construct their gender identity. The study also provides frequency counts of some of the most commonly employed linguistic devices by males and females to construct their identity in same- and mixed-sex conversations.

The data used for this study consists of fifteen conversations, equally divided between same-sex, whether male-male or female-female, and mixed-sex groups. The total length of these conversations is approximately ten hours, and the analysed parts are only the humorous parts where speakers construct their gender identity. The participants are all Englishspeaking foreigners from the United States and the United Kingdom. They are staying in Egypt for various purposes, such as tourism, studying, or working. Some of them also live in Egypt either because they work, or are married to Egyptians. The participants are all university students and graduates who work in various professions, and they all speak Standard English. 
The analysed conversations have been recorded from various social settings, such as social clubs in Alexandria, Bibliotheca Alexandrina, touristic places, and the Teaching Arabic for Foreigner Learners Center (TAFL) in the Faculty of Arts, Alexandria University. In the TAFL center, there are university students from a number of American and British universities. The conversations have been recorded after obtaining the participants' permission. In the study, they are given pseudo-names to maintain their privacy. The number of participants in every conversation ranges from two to four.

\section{Theoretical Background}

Conversation analysis developed in the 1960s and 1970s by Harvey Sacks, Gaul Jefferson, and Emanuel Schegloff. It describes the social organization of talk or conversations from the perspective of the participants (Ohara \& Saft, 2003:153). Conversation analysts usually focus on the extent to which conversations are "interactionally achieved" (Sacks, 1992). In other words, participants form a given social order in which they use the context to interpret what is going on (Heritage \& Drew 1992:17-19). 
Schegloff (1992:192) indicates that in CA what is relevant for the analyst is what is relevant for the participants. Therefore, gender as a variable is only relevant in a given conversation only when participants make it relevant (Tracy, 1998:15). This means that the analyst should not impose his/her beliefs on the data. This is different from the feminist approach which indicates that it is impossible for the analyst to take an objective impartial position, and should be influenced by his/her beliefs and experiences when analyzing the data. Thus, the feminist approach of analysis starts from a certain perspective (Weatherall, 2000: 288).

The interactional aspect of conversations can be seen in the use of humour which is a universal human phenomenon found in all societies. Wehmeier et al. (2005:761) define it as "the quantity in something that makes it funny or amusing". Having a sense of humour is a quality that is highly valued in people. A person who does not have a sense of humour is an incomplete person (Wickberg, 1998: 85). Humour indicates solidarity and consensus between speakers. Thus, it is close to positive politeness than to negative politeness strategies of non-imposition. Humour is usually associated with unexpected behaviour, whereas formal 
rules of behaviour are expected or predictable (Zajdman, 1997: 327).

Mulkay (1988) distinguishes between serious and humorous modes in conversations. In the former, speakers in the on-going conversation know that there is a single and objective reality agreed upon regarding what is said. In this kind of mode, people avoid selfcontradiction, resolve disagreements, and be clear in what is said. In the latter, ambiguity is accepted as well as multiple interpretations of reality. Thus, it is controlled nonsense.

Speakers who make humorous comments must ensure that their remarks are heard in the immediate contexts (Lampert \& Ervin-Tripp, 2006: 54). Thus, they can make their humorous utterances by using markers, such as "Have you heard this one..." This is a signal for hearers "that the conversation is entering a humorous frame" (Yamaguchi, 1988: 326). In the case of spontaneous jokes, "the hearer has to make a...hypothesis based in assumptions about the intended humorous quality of the utterance. Thus, there may be...cues in the context that what is being said... should not be taken seriously" (Yus, 2003: 1299). In humorous utterances, the hearer has to accept it and change his 
interpretive expectations (Mulkay, 1988: 10). "When the hearer expects the humorous quality of the coming utterances in a given conversation, the interpretive procedures will vary to be able to understand the humorous effects of what will be said" (Yus, 2003: 1300).

Humour has a number of functions. It can be used to express common points of view and solidarity as well as to create a positive self-image (Keltner et al., 2001: 450). These functions are related to Brown and Levinson's 2004 positive politeness strategy where common views among speakers are expressed (Hay, 2000: 716). Humour also helps to express repressed emotions such as anger and tension (Ervin- Tripp \& Lampert, 1997; Rogerson- Revell, 2007: 6). Humour has another function related to superiority as when laughing at the behaviour, attitudes, or misfortunes of others, i.e. ridicule. This function relates to Brown and Levinson's 2004 negative face.

Humour is of two main types, namely supportive and contestive. In the former, humorous utterances are used to agree with, add to, or elaborate arguments of previous utterances. In the latter, humorous utterances challenge or disagree with the propositions in the previous contributions (Holmes \& Marra, 2002: 1687). 
There are also different styles of humour. The first is collaboratively-constructed humour sequences. By adopting this style, participants tend to integrate contributions tightly using devices, such as echoing, mirroring, or completing each other's utterances. The effect is an enjoyable humorous interaction (Holmes \& Marra, 2002: 1689).This kind is called "all together now humor". The second style is competitive constructed humour. This kind is called "one at a time humor" Coates (1989: 120). In this style, there are few overlaps between participants.

The relationship between gender and humour in conversations is complicated because gender differences are clearly manifested in humorous interaction. Males' humour is exclusive, challenging, segmented, preformulated, and self- aggrandizing (Jenkins, 1985: 128). Man rarely uses self-directed humour about their own personal experiences among other males to keep their positive self- image. However, in mixed-sex groups, they use self- deprecating and wisecracks. Females' humour is cooperative, inclusive, supportive, integrated, spontaneous, and self-healing. Females' humour also creates solidarity, indicates intimacy among participants (Crawford, 2003: 1422). Women tell 
humorous anecdotes about situation in which they are depicted as helpless or overwhelmed by events (Coates, 1996: 110). This is done to get other participants to participate in the on-going conversation. Women use self-directed humour among other women but rarely in mixed-sex groups (Crawford, 2003: 1422). Jenkins (1985) indicates that males' humour is more performance-based and use formulaic jokes. This establishes them as credible performers and gives them audience, while women rely on the surrounding context in the creation of their humour, and use language in a supportive way, i.e. spontaneous humour.

The identity of a person is based on past and present experiences in a given sociocultural and historical context (Lanehart, 1996: 322- 325). Power is an important sociological concept when analysing identity. It is manifested when speakers play important roles in society and can affect others. Therefore, power is usually attributed to males because the society's ideology is based on masculine dominance (Goffman, 1963: 89). Those who are out of power or less powerful must be supportive, polite, and conform to societal values (Lakoff, 1990: 85). Traditional views regarding females always portray them as less powerful than 
males. Therefore, it can be said that femininity is a culturally defined form of mitigation or denial of power, whereas masculinity is an affirmation of power (Eckert, 1989: 257). However, because of the emergence of the feminist movement and its criticism of males dominance and behaviour, the views of males regarding females started to change, and the figure of the "new man" has emerged; one who is soft, caring, and respects all women's roles in life (Rutherford, 1988).

The identity of an individual is built through language (Rojagopalon as cited in Ferreira, 2003: 4748). Indeed, language is used to represent our identities and to express our rejection or acceptance of the values and traditions in a given society (Cameron, 1995: 122; Holmes, 1997: 195). This is done to express, create, or subvert various social meanings, such as anger, frustration, agreement, disagreement, uncertainty, friendliness, etc (Hopper \& LeBaron, 1998; Weatherall, 2000). Conversational humour helps in constructing and presenting a person's gender identity. One way in which males and females use humour is in personal narratives and anecdotes (Coates, 1996: 110). These narrative accounts can provide insights about the 
gender stereotypes to which participants relate (Holmes, 2006: 38).

Gender identity in a given interaction depends on the participants' familiarity with the significance of some linguistic devices. Pragmatic particles are linguistic forms that express the speaker's uncertainty about a proposition (Coates, 1993: 116). They are forms such as "well" and "you know". Lakoff (1975: 54) maintains that females use more pragmatic particles than males because they are raised up to believe that it is not feminine to asserting themselves.

Another linguistic device used to construct gender identity is tag questions. They are linguistic forms associated with tentativeness and are used to describe the strength of assertions (Lakoff, 1975: 68; Coates, 1993: 119). Moreover, tag questions have four main functions: facilitative, (inviting participation), softening (attenuating a criticism), epistemic (expressing uncertainty), and challenging (expressing aggression) (Holmes, 1997: 200). Tag questions are used more by females, who favour solidarity in their speech, to express friendliness, uncertainty, and informality (Lakoff, 1975; O'Barr \& Atkins, 1980). 
Imperative forms also help in constructing a speaker's gender identity. An imperative expresses a command, which in turn belongs to the speech act of directives. A directive is defined by Coates (1993: 124) as "a speech act which tries to get someone to do something". Males tend to use explicit imperatives, while females use mitigated forms of imperatives, such as "let's go" and the two modal verbs "can" and "could" (Goodwin 1990; West, 1990).Thus, imperatives in some cultures are related to masculinity (Ochs, 1992: 341).

Emphatic stress is another linguistic device that can be related to constructing identity. An emphatically stressed lexical item is usually produced using more air from the lungs, and more muscular effort is exerted in its production. It is usually louder and longer in duration than other lexical items (Davenport \& Hannahs, 1998: 78). An important function of emphatic stress in speech is to emphasize the idea expressed. Emphatic stress is used more by females (Lakoff, 1975: 120; Richards et al., 1996:356; Tannen, 1996: 110).

Repetition is another linguistic device that can be related to constructing gender identity. It is a component of unplanned discourse. Sometimes when a 
speaker says something, the next speaker responds by repeating a part of what the former speaker has said, whether a lexical item, a grammatical structure, or a given meaning. This is one feature of conversations. When parts or elements of talk, whether lexical items, grammatical structures, meaning, etc, are repeated, a coherent piece of discourse is formed. An important function of repetition is to signal solidarity among speakers, and indicate the involvement of speakers in the on-going conversation (Coates, 1996: 203-204, 230). Tannen (1987: 89; 1989: 97) maintains that repetition is a way that shows one's response and acceptance of others' utterances. Females tend to use repetition to respond to an interlocutor's narration or explanation of something. Repetition in males' speech tends to be less positively polite (Brown, 1993: 148).

Cognitive verbs are also related to constructing gender identity. They include verbs, such as "think" and "know". They belong to Halliday's mental processes verbs which usually involve a senser "one who is thinking" and a phenomenon "what is sensed" (Halliday, 1994: 117-118). Females are more expressive of their opinions, feelings, and emotions more than males, and so cognitive verbs are one way used to do 
this (Mulac et al., 1990: 450). This can be due to the increasing desire and acceptance of females' participation in conversations to express their opinions and feelings (Aries, 1982: 132).

The first person singular pronoun "I" is another linguistic device that can be used in constructing gender identity. Mulac et al. (2001: 130) indicate that males use the first person singular pronoun "I" more than females. Since it indicates individualism, this pronoun fits the male stereotype more than the female stereotype. However, Mehl and Pennebaker (2003: 865) indicate that females are more likely to use the first person pronoun "I". Fasulo and Zucchermaglio (2002) establish a typology of I-marked utterances, and identify four basic classes based on their semantic and pragmatic meaning. Only two of these I-marked utterances are relevant to the present study, namely "epistemic I" and "decisional I". The former is used to refer to the speaker's state of knowledge. Epistemics include parentheticals of probability, such as "I think", parentheticals of necessity, such as "I am convinced", verbs of perception, as "I see", references to cognitive states, as "I remember", and expressions indicating one's tendency to support a certain action or attitude, 
such as "I favour" and "I agree". The latter is used when the speaker indicates his stance concerning an action or a proposal and commits himself to it. Decisionals include modals, such as "I can", and "I shall". They can also be presentations of an action or an attitude in the conditional mood, such as "I'd do $X$ " (Fasulo \& Zucchermaglio, 2002: 1126-1128). Generally, pronouns are used as to indicate power, where one speaker has more power than another, and can also indicate solidarity between speakers; i.e. equality between speakers (Tannen, 1993: 167).

There are various studies about humour which cover various areas, such as humour in business contexts (Holmes, 2000; Holmes \& Marra 2002; Rogerson-Revell, 2007). There are also studies about humour and face-threatening acts (Zajdman, 1995), humour and gender (Crawford, 2003; Kotthoff, 2006), and linguistic devices used by males and females in constructing their identity (Holmes, 1997). However, to the researcher's knowledge no studies have been carried out concerning how males and females use spontaneous humorous contexts to construct their gender identity and the linguistic devices they use to do so. The present study attempts to fill in this gap. 
4. Analysis

\subsection{Male-Male Conversations}

To be able to show how males construct their own gender identity and the linguistic devices they use in their humorous conversations, it is essential to analyse some male-male conversations.

Extract (1): Context: (Ross and Ben are two male friends talking at the TAFL Center about the clothes of the former)

Ross: Damn it. I have a date tomorrow with Ann. I wanna look cool.

Ben: Well, you know, I know a good shop here in Alex. I can take you there.

Ross: Well, I have to look cool. You know she teased me yesterday about the T-shirts I wear.

Ben: Oh, well, I can see why. I totally agree. This is a nice T-shirt you're wearing (Laughs). Take me as your example in life. Can't you see how chic I am?[ Ross: [Oh, stop this, you idiot.

In extract (1), Ben and Ross are two friends at the TAFL Center talking about buying some new clothes for the latter who has a date with his girlfriend, Ann. In turn (2), Ben uses the epistemic " $I$ " followed by the cognitive verb "know" when he says, "I know a good shop here in Alex" to express his knowledge of good 
shops in Alexandria. In turn (3), Ross says that he has to look cool as his girlfriend teased him about his Tshirts. Ben, in the next turn, indicates that he agrees with Ann's opinion by making the short statement "I can see why." He also says, "I totally agree", in which epistemic " $I$ " is used to indicate his knowledge of what his friend's girlfriend says and his agreement with her. Then, he makes the teasing comment "This is a nice Tshirt you're wearing" as a sarcastic remark to further emphasize that he does not like Ross's T-shirts. Ben then makes the humorous comment "Take me as your example in life. Can't you see how chic I am?" By making this comment he is trying to prove that his taste in choosing clothes is better than Ross's. In this humorous comment, the imperative form "take me" is used followed by the negative question "Can't you see how chic I am?" This also shows that he has feelings of superiority over his friend who has a poor taste in choosing his clothes. In this negative question, epistemic "I" is used as an identity marker through which the speaker indicates how he perceives himself as a fashionable chic person. Ross, in the final turn, does not want Ben to continue what he is saying using the overlapping utterance "Oh, stop this, you idiot." The 
imperative form "stop this" signals that Ross rejects what Ben is saying. Ross also uses the informal word "idiot" to make his friend stop his sarcasm.

Extract (2): Context: (Patrick and John are two friends working at an international maritime company talking together in the social club about a report the former had to finish)

Patrick: Here is the report you asked me to write. It's finally finished. I'm really dead tired.

John: Yeah (3). It is finally finished. You look awful, man.

Patrick: "Awful" is not enough. Have a quick look and release me.

John: "Oh, release me". Beg me more (2) (Laughs).

Patrick: Hey, stop that. I'm really dead tired. I would've killed you if I were fine.

John: (Short laugh while nodding his head) You know, you look awful. You're dead tired, aren't you?

In extract (2), Patrick and John are two Americans working at an international maritime, and sometimes they meet at the social club. John has asked Patrick to finish a report for him. The latter is very tired and wants the former to take the report and to let him go. So, Patrick, in turn (3), says to John "release me." By using the imperative form, Patrick implies that he is 
aware of the power John has over him. Then, in turn(4), John repeats Patrick's utterance "release me" twice to tease his friend Patrick and to make fun of what he says. John then says while laughing "beg me more" in which the imperative form is used to manifest his power over his friend. The imperative form is repeated twice to emphasize the speaker's sense of power. In turn (5), Patrick says "stop that...fine", in which the imperative form "stop that" is used to show that he does not accept what his friend is saying. Moreover, the use of the idiomatic expression "I would've killed you" that indicates a negative action on the part of the speaker. This shows that Patrick challenges John's power over him to construct his positive self-identity and to prove that he is not weak. He refuses to be forced to do anything. In the final turn, John laughs shortly while nodding his head and says, "You know", which is a pragmatic particle, to express that he understands his friend's tiredness. He, then, makes the humorous remark, "You're dead...aren't you?" in which he uses the tag question "aren't you?" to further emphasize this. 
Extract (3): Context: (Jimmy and Mike are two teen friends talking together in the social club about an oldfashioned suit of the former's grandfather)

Jimmy: Look what I found when I was cleaning my closet.

Mike: What's this?

Jimmy: It's an old album. I don't know how it came to my closet. Look at the suit grandpa is wearing. It's very old-fashioned. (Laughs)

Mike: Well, I wouldn't imagine wearing something like that. It'll destroy my self-image. Oh my God, it looks so funny. (Laughs)

Jimmy: I really can't imagine you wearing a suit like that. (Laughs) I would kill myself if I wear something like that.

In extract (3), Jimmy and Mike are two teen friends talking together in the social club about Jimmy's grandfather's suit. The former tells the latter about a picture of his grandfather wearing an oldfashioned suit. In turn (4), Mike tells his friend that the suit is funny, and he cannot imagine himself wearing something like that as it will destroy his self-image. This shows that Mike is a kind of person who tries to keep a positive self-image and presents himself as a stylish and fashionable young man. Mike begins his turn with the pragmatic particle "Well" to express that he agrees with his friend's opinion regarding the old-fashioned 
suit. The use of the modal verb "will" indicates that he is certain that his identity will be negatively affected. In the final turn, Jimmy says that he cannot imagine his friend wearing an old-fashioned suit. This is a near repetition of what Mike says in the previous turn. This shows that he is aware of his friend's deep concern for keeping a positive self-image as a young man of style in choosing clothes. Finally, Jimmy says, "I would kill ...that", in which decisional " $I$ " is used to indicate that he does not like this kind of suits. Therefore, he portrays himself as a young man who follows the latest style in wearing clothes exactly as his friend.

\subsection{Female- Female Conversations}

In order to clarify how females construct their gender identity and the linguistic devices they use in their humorous conversations, it is essential to analyse some female-female conversations.

Extract (4): Context: (Monica and Lydia are two aged friends talking in the social club about the costs of weddings in Egypt)

Monica: I've heard that weddings here in Egypt cost a fortune. Some say that it's a four-million dollar industry. 
Lydia: Yeah, you know, it seems that my son in his wedding is responsible for something like half that sum. (Laughs) His groom's demands for the wedding party are endless. Well, (Laughs) I think I'm a moving bank.

Monica: Oh, don't tell me. I know you're the one who has to pay for all of these demands.

Lydia: I should be up to the event, shouldn't I?

In extract (4), Monica and Lydia are two aged American ladies who have been living in Egypt after marrying Egyptians. They are discussing the high costs of weddings in Egypt. Lydia, in turn (2), says the humorous utterance "it seems that my...sum" followed by the explanation that his groom's demands for the wedding party are endless. She also uses the pragmatic particle "well" to indicate that she is going to elaborate on what she says about the expenses of the wedding. Then, she laughs and says, "I think...bank", which is a metaphor used to show that she supports her son in paying the expenses of his wedding party. In this same utterance, she uses the epistemic " $I$ " in "I think" to indicate her full knowledge and awareness of her financial responsibility towards her son. She also uses the cognitive verb "think" also to indicate that she understands the importance of her financial role. It is clear that she presents herself as a woman of great 
capabilities, and with a strong ability to carry out difficult missions and responsibilities. Thus, she is neither weak nor totally dependent on her husband as he is supposedly the money provider. In turn (3), Monica agrees with her friend when she says, "I know...demands" which is a paraphrase of what Lydia says. In the final turn, Lydia further emphasizes her important role in supporting her son financially by saying, "I should...shouldn't I?" In the utterance, she uses the epistemic "I" in "I should be" to manifest her obligation and duty towards her son as a mother.

Extract (5): Context: (Leslie and Janet are two university friends in the TAFL Center talking about the latter's skirt)

Leslie: How do you like my skirt?

Janet: Do you want a compliment or the truth?

Leslie: Don't you like it?

Janet: (Laughs) I can't hide my true opinion.

Leslie: Oh, I know these feelings of yours. You haven't even tried to say a good word for me. I'm your friend. Remember? I know I have a good taste in choosing clothes.

Janet: (Laughs) Well, not to the extent you imagine.

Leslie: Don't laugh young lady. It seems you don't want to admit my great taste in choosing clothes. 
In extract (5), Leslie and Janet are two university friends talking about the latter's opinion in the former's skirt. Janet laughs when she says in turn (4) that she cannot hide her opinion which insinuates that she does not like it. In turn (5), Leslie says, "I know...yours." She uses the epistemic "I" to show that she knows that her friend does not like the skirt. To further emphasize this, she uses the cognitive verb "know". She then says, "You haven't...Remember?' in an attempt to gain her friend's sympathy and make her say that she likes the skirt. Leslie then adds that she knows she has a good taste in choosing clothes. She uses the epistemic " $I$ " and the cognitive verb "Know" in "I know I have a good taste in choosing clothes" to indicate her good taste in choosing clothes to promote a positive self-image as a person who has a good taste in choosing clothes. The utterance also is in the declarative form to express a definite truth that cannot be challenged. In turn (6), Janet laughs and responds by saying that her good taste is not to the extent she imagines. This shows that she is not convinced of what her friend says. In the final turn, Leslie uses the imperative utterance "Don't laugh" followed by the declarative utterance "It seems...clothes." This is an attempt to challenge what 
her friend says in the previous turn and express her disagreement on what is said.

Extract (6): Context: (Two friends working in an international drugs company in Alexandria talking about gender discrimination at work)

Mary: You know, sometimes I feel there is gender discrimination at work, and when this happens, I try to switch it to a funny situation just to get over the situation.

Janet: Why do you say that?

Mary: Yesterday, I finished the report I had to write. So, I just sent it with a janitor to sign it from the manager.

Janet: So?

Mary: When I saw him in a meeting later that day, he was trying to be funny, and said, "You women like somebody else to do the work for you, like sending the janitor to sign a report".

Janet: What did you say?

Mary: Well, to tease him I said that men want women to be under their mercy, and come begging to them whenever they want something.

Janet: (Laughs) This will never ever happen.

Mary: (Laughs) Yeah, this will never ever happen. We'll never kneel to them.

Janet: Good girl you told him that.

In extract (6), Mary and Janet are two American friends working in an international drugs company in Alexandria. In the conversation, Mary narrates a 
personal situation about gender discrimination at work. She tells her friend about when she sent a janitor to sign a report from the manager, and when she met him later that same day, he teased her saying, "You women...report." As a result, Mary teased him saying that men want women to be under their mercy and come beg to them. It can be noticed that in the narrative part, Mary portrays herself as a capable and strong woman of action who can defend women's rights. In turn (8), Janet refuses this traditional view by laughing and saying that this will never happen. Mary, in turn (9), laughs and expresses her agreement by using the agreement marker "Yeah" and by repeating her friend's previous utterance, "this will never happen." Then, she says, "We'll...them" to further emphasize this. In her utterance, Mary uses the modal verb "will" to assert that women have strong characters, their own identities, and will never be under men's mercy. It can also be noticed that Mary uses the inclusive "we" in "We'll never kneel to them", which includes not only her but other women as well.

\subsection{Mixed-sex Conversations}

To be able to show how males and females construct their gender identity in mixed-sex humorous 
conversations and the linguistic devices used in them, it is vital to analyse some of these conversations.

Extract (7): Context: (Jackson and Monica are a married couple at the American school in Alex discussing the wife's hair style)

Monica: What do you think of my new hair style?

Jackson: (Laughs) Dear, I think I can see your scalp.

Monica: See my scalp. Don't you love it?

Jackson: Yeah (2), you've got jellyfish in your hair. (Laughs)

Monica: JELLYFISH stop this. This is the latest fashion. You just don't understand anything about fashionable hairstyles. My God, my husband doesn't know the least thing about fashionable hairstyles. (Laughs)

Jackson: Oh, it's really a pity. You women really need men, don't you? (Laughs)

In extract (7), Jackson and Monica are a married couple, who work as teachers at the American school in Alexandria. They are discussing Monica's new hairstyle. In turn (2), Jackson laughs when his wife asks him what he thinks of her new hairstyle, and he says he can see her scalp. In turn (3), Monica indicates her disagreement by repeating her husband's utterance "see my scalp." Then, she asks him the negative question "Don't you love it?" as she expects him to say 
that he likes her hairstyle. In other words, she expects a positive answer. In the next turn, he teases her by saying that she has got jellyfish in her hair and laughs. In turn (5), she repeats her husband's word "jellyfish" and emphatically stresses it to manifest her disagreement with what her husband says. Then, she explains that this is the latest fashion and accuses her husband of not knowing anything about hairstyles. By doing so, she implies that she is the one who knows all about fashion. Thus, she portrays herself as knowledgeable to present herself positively to her husband. In the final turn, Jackson responds sarcastically by saying, "It's really a pity...don't you?" and laughs to indicate that he has the traditional view about women that they cannot live without men and are totally dependent on them. This also manifests that he thinks that women only care about their appearance. He uses the negative tag question "don't you?" to further emphasise his view that women need men. So, a positive answer is expected as a confirmation of what he says. 
Extract (8): Context: (Jason, Sally, and Michael are university friends at the TAFL Center discussing Sally's makeup)

Jason: Nice makeup, Sally.

Sally: Yeah (2). Thanks for the compliment.

Michael: you girls can't do without makeup, can you? (Laughs)

Sally: Watch what you're saying. (Laughs) Well, remember that you men can't live without us, women. (Laughs)

Jason: (Laughs) Yeah, I know this same old story. You know, we guys are cute by nature. (Long laugh)

In extract (8), Jason, sally, and Michael are American university students at the TAFL center discussing sally's makeup. In turn (3), Michael says, "You girls...can you?" and laughs. He uses the tag question "can you?" to indicate that he expects a negative answer because women are known to be fond of makeup, and never go out without wearing it. Therefore, he presents the traditional males' view about women wearing makeup. In turn (4), sally disagrees with him by using the imperative "Watch what you're saying." This is followed by the pragmatic particle "well" to indicate that what will follow is a truth that cannot be changed. Then, she uses the imperative 
"Remember...women" and laughs. By using the imperative verb "remember", she tries to construct her positive self-identity by explicitly stating the generalization that men cannot live without women. In the final turn, Jason is sarcastic and says, "I know this same old story" to imply that what Sally says is what is always said by women. So, it lost its meaning. He uses the epistemic "I" followed by the cognitive verb "know" to indicate that he knows that women always say this. What Jason says is an attempt by him to underestimate what Sally says in the previous turn to keep men's traditional view that women care about their appearance. He finally says, "You know...nature" in which the pragmatic particle "you know" is a kind of confirmation of the fact that men do not need any makeup as they are naturally handsome. He also uses the inclusive "we" to show that what he says includes all men.

Extract (9): Context: (Christina and Ahmed talking at the cafeteria of Bibliotheca Alexandrina)

Christine: This is the first time for me to visit the Bibliotheca although I've been in Egypt for three months.

Ahmed: It's really a great place. 
Christine: I've noticed something weird, however. Some Egyptians make fun of tourist who read from touristic brochures. (Laughs)

Ahmed: Well, I know that.

Christine: You wouldn't imagine what I did. (Laughs) I hid the touristic brochure inside a comic magazine.

Ahmed: I know what you're talking about, and I' do the same if I were you.

Christine: Do you BELIEVE that? (Laughs) I can't imagine I am a respectable academic researcher, you know, reading information from a comic magazine just to avoid funny comments from the Egyptians.

Ahmed: I can imagine that. (Laughs)

In extract (9), Christine is a British academic researcher visiting Alexandria, and Ahmed is her Egyptian friend. They are talking about the Egyptians' attitude towards tourists reading from touristic brochures. In turn (3), Christine laughs and tells Ahmed that she noticed that Egyptians make fun of tourists who read from touristic brochures." In turn (4), Ahmed says, "Well, I know that." He begins his turn with the pragmatic particle "well" to confirm what Christine has said in the previous turn, and to indicate that it is an embarrassing truth. Then, he uses the epistemic" I" followed by the cognitive verb "know" to indicate his knowledge of what she says. In turn (5), 
Christine laughs when she says she had to hide the touristic brochure she was reading from inside a comic magazine. In turn (6), Ahmed signals his full understanding of what she says by saying, "I know...you." In "I know", he uses the epistemic "I" followed by the cognitive verb "know" to indicate that he knows what he is talking about. Moreover, in "'I'd do the same if I were you", he uses the decisional "I" to clarify his stance to what Christine has done, and that he agrees with her. In the next turn, Christine indicates her astonishment and disagreement with Egyptians' attitudes by saying, "Do you believe that?" She emphatically stresses "believe" to further emphasise her astonishment of the Egyptians' attitude. She then laughs and tells him that she cannot believe she, an academic researcher, is reading from a comic magazine. By saying this, she constructs her academic identity, and portrays herself as a serious woman. She also uses the pragmatic particle "you know" in "I can't imagine...Egyptians" to further emphasise to her male friend her respectable academic identity. In the final turn, Ahmed once more indicates his agreement and understanding of what she says by telling her that he can imagine that. In this turn, he says, "I can imagine 
that" in which he uses the epistemic " $I$ " to indicate his knowledge of what she says. This is followed by the cognitive verb "imagine" to further emphasise this.

\section{Results and Discussion}

5.1 Frequency of Using some Linguistic Devices in Humorous Utterances in the Data.

The data reveals that males and females use various linguistic devices to construct their gender identity in humorous utterances. These devices are: epistemic "I", decisional "I", imperatives, repetition of the former speaker's previous utterances, cognitive verbs, emphatic stress, tag questions and pragmatic particles. Table (1) illustrates the frequency of using these linguistic devices in the analysed data.

Table (1) Frequency of linguistic devices used by males and females to construct their gender identity in humorous utterances in the analysed data

\begin{tabular}{|c|c|c|c|}
\hline Linguistic device & Males & Females & Total \\
\hline Epistemic "I" & $26(54 \%)$ & $22(46 \%)$ & $48(100 \%)$ \\
\hline Decisional "I" & $20(50 \%)$ & $20(50 \%)$ & $40(100 \%)$ \\
\hline Imperatives & $18(58 \%)$ & $13(42 \%)$ & $31(100 \%)$ \\
\hline $\begin{array}{l}\text { Repetition of the former } \\
\text { speaker's previous } \\
\text { utterance(s) }\end{array}$ & $17(57 \%)$ & $12(43 \%)$ & $29(100 \%)$ \\
\hline Cognitive verbs & $16(41 \%)$ & $2^{r}(59 \%)$ & $3^{9}(100 \%)$ \\
\hline Emphatic stress & & $16(100 \%)$ & $16(100 \%)$ \\
\hline Tag qu & $17(48.5 \%)$ & $18(51 \%)$ & $35(100 \%)$ \\
\hline Pragmatic particles & $22(45 \%)$ & $27(55 \%)$ & $49(100 \%)$ \\
\hline
\end{tabular}


Table (1) indicates that the mostly used linguistic devices to construct gender identity by males are: imperatives (58\%), followed by repetition of the former speaker's previous utterance(s) (57\%), epistemic "I" (54\%), decisional "I" (50\%), tag questions (48.5\%), and pragmatic particles $(45 \%)$. The least used linguistic device is cognitive verbs (41.1\%). Males do not use emphatic stress to construct their gender identity. However, the most commonly used linguistic devices by females to perform the same functions are: emphatic stress, which is only used by females (100\%), followed by cognitive verbs $(59 \%)$, pragmatic particles $(55 \%)$, tag questions (51\%), decisional "I" (50\%), epistemic "I" $(46 \%)$, repetition of the former speaker's previous utterance(s) $(43 \%)$, and imperatives (42\%). Table (1) also shows that epistemic "I" is used by males (26 times, $54 \%$ ) more than females ( 22 times, $46 \%$ ). This is done to show that males like to talk about what they know openly in humorous conversations more than females. As for decisional "I", it is used equally (20 times, 50\%) by both males and females to indicate that both have their own opinions to which they are committed. Imperatives in humorous utterances are used more by males (18 times, $58 \%$ ) than by females (13 times, $42 \%$ ) 
due to the power society gives to males, so they feel superior. This gives them a ready-made positive selfimage. Repetition of the former speaker's previous humorous utterance(s) is used by males (17 times, 57\%) more than females (12 times, $43 \%$ ). This shows that males use other speakers' previous utterances as a source of humour more than females who do not do this as they usually care about and consider the feelings of other speakers. However, females use repetition of the former speakers' utterances in humour to emphasize what they say, and to make sure that their humorous comments are understood by other participants in the on-going conversation. Cognitive verbs are used by females ( 23 times, $59 \%$ ) more than by males (16 times, 41\%). This is because the former can be more expressive of what they know and their opinions than the latter. Emphatic stress in humorous utterances is only used by females (16 times, $100 \%$ ) in the analysed data. This indicates that they want other participants to listen to what they say humorously and appreciate it. Tag questions are used by females (18 times, $51 \%$ ) more than males (17 times, $48.5 \%$ ). This is because females, due to the uncertainty they might feel, want to elicit confirmation to what they say humorously and make 
other participants accept it. Pragmatic particles are used in humorous utterances by females ( 27 times, $55 \%$ ) more than males ( 22 times, $45 \%$ ). This is because females favour solidarity, friendliness, and agreement in their speech more than males

Table (2) demonstrates the frequency of occurrence of the analysed linguistic devices employed by males and females to construct their identity in same- and mixed-sex humorous conversations.

Table (2) Frequency of the analysed linguistic devices used by males and females to construct their gender identity in same- and mixed-sex humorous conversations

\begin{tabular}{|c|c|c|c|c|c|c|}
\hline$\underset{\text { Device }}{\text { Linguistic }}$ & \multicolumn{3}{|c|}{ Males } & \multicolumn{3}{|c|}{ Females } \\
\hline \multirow[b]{2}{*}{ Epistemic "I" } & $\begin{array}{c}\text { Same-sex } \\
\text { conversations }\end{array}$ & $\begin{array}{c}\text { Mixed-sex } \\
\text { Conversati } \\
\text { ons } \\
\end{array}$ & Total & $\begin{array}{c}\text { Same-sex } \\
\text { conversations }\end{array}$ & $\begin{array}{c}\text { Mixed- sex } \\
\text { Conversations }\end{array}$ & Total \\
\hline & $(61.6 \%)$ & $\stackrel{10}{(38.4 \%)}$ & $\stackrel{26}{(100 \%)}$ & $\begin{array}{c}12 \\
(54.6 \%)\end{array}$ & $\begin{array}{c}10 \\
(45.4 \%)\end{array}$ & $\stackrel{22}{(100 \%)}$ \\
\hline Decisional & $(\mathbf{5 0 \%})$ & $(\mathbf{5 0 \%})$ & $\stackrel{20}{(100 \%)}$ & $(\mathbf{5 0 \%})$ & $(\mathbf{5 0 \%})$ & $\stackrel{20}{(100 \%)}$ \\
\hline Imperatives & $\begin{array}{c}10 \\
(55.6 \%)\end{array}$ & $\begin{array}{c}8 \\
(44.4 \%)\end{array}$ & $\begin{array}{c}18 \\
(100 \%)\end{array}$ & $\begin{array}{c}13 \\
(100 \%)\end{array}$ & - & $13(100 \%)$ \\
\hline $\begin{array}{l}\text { Repetition of } \\
\text { the former } \\
\text { speaker's } \\
\text { previous } \\
\text { utterance(s) }\end{array}$ & (53\%) & $\stackrel{8}{8}$ & $\begin{array}{c}17 \\
(100 \%)\end{array}$ & $\stackrel{8}{8}$ & $(33.4 \%)$ & $12(100 \%)$ \\
\hline$\underset{\text { verbs }}{\text { Cognitive }}$ & $\underset{(50 \%)}{8}$ & $(\mathbf{8})$ & $\begin{array}{c}16 \\
(100 \%)\end{array}$ & $(60.8 \%)$ & (39.2 \%) & $23(100 \%)$ \\
\hline $\begin{array}{c}\text { Emphatic } \\
\text { stress }\end{array}$ & - & - & - & - & $16 \%$ & $\begin{array}{c}16 \\
(100 \%)\end{array}$ \\
\hline Tag questions & $(65 \%)$ & $(35 \%)$ & $\begin{array}{c}17 \\
(100 \%)\end{array}$ & $\begin{array}{c}10 \\
(55.6 \%)\end{array}$ & $\begin{array}{c}8 \\
(44.4 \%)\end{array}$ & $18(100 \%)$ \\
\hline $\begin{array}{c}\text { Pragmatic } \\
\text { particles }\end{array}$ & $\begin{array}{c}11 \\
(50 \%)\end{array}$ & $\begin{array}{c}11 \\
(50 \%)\end{array}$ & $\begin{array}{c}22 \\
(100 \%)\end{array}$ & $\begin{array}{c}16 \\
(59 \%)\end{array}$ & $\begin{array}{c}11 \\
(41 \%)\end{array}$ & $\begin{array}{c}27 \\
(100 \%)\end{array}$ \\
\hline
\end{tabular}


Table (2) shows that the most commonly used linguistic devices by males in same-sex conversations are: tag questions (65\%), followed by epistemic "I" (61.6\%), imperatives $(55.6 \%)$, and repetition of the former speaker's previous utterance(s) $(53 \%)$. The least used devices are decisional "I", cognitive verbs and pragmatic particles, all of which are used equally $(50 \%)$. Males do not use emphatic stress in the analysed data. Moreover, the most commonly used linguistic devices by males in mixed-sex conversations are: decisional "I", pragmatic particles, and cognitive verbs, all of which are used equally (50\%). These are followed by repetition of the former speaker's utterance(s) (47\%), followed by imperatives (44.4\%), and epistemic "I" (38.4\%). The least used device is tag questions (35\%). Males do not use emphatic stress at all. Regarding females, the most commonly used linguistic devices in same-sex conversations are: emphatic stress, which is only used in same-sex conversations (100\%), followed by repetition of the former speaker's previous utterance(s) (66.6\%), cognitive verbs $(60.8 \%)$, pragmatic particles $(59 \%)$, tag questions $((55.6 \%)$, and epistemic "I" (54.6\%). The least used device is decisional "I" (50\%). In addition, the most commonly 
used linguistic devices by females in mixed-sex conversations are: emphatic stress $(100 \%)$, which is only used by females, followed by decisional "I" (50\%), epistemic "I" (45.5\%), tag questions (44.4\%), pragmatic particles $(41 \%)$, and cognitive verbs $(39.2 \%)$. The least used linguistic device is repetition of the former speaker's utterance(s) (33.4\%).

Table (2) also shows that in humorous conversations, epistemic "I" is used more by males in same-sex conversations (16 times, 61.6\%) more than in mixed-sex ones (10 times, 38.4\%). A male speaker does so to show the other males that he is knowledgeable. It is also used by females in same-sex conversations (12 times, 54.6\%) more than in mixed-sex ones (10 times. 45.5\%). This shows that women among each other are able express their opinions and talk about what they know freely without constraints because of the existence of males. In humorous utterances, decisional "I" is used equally by both males and females in same- and mixedsex conversations ( 10 times, $50 \%$ ). This shows that both males and females express their opinions freely and have no problem in expressing their own free will. Imperatives in humorous utterances are used by males in same-sex conversations (10 times, $\mathbf{5 5 . 6 \%}$ ) more than 
in mixed-sex ones ( 8 times, $44.4 \%$ ). This is because males use imperatives as a way to exercise their power when they are among each other. However, they do not do this so much in the presence of females, to give themselves- males- a positive self-image and to show that they are not against females in whatever they say. Concerning females, they use imperatives in their humour only in same-sex conversations (13 times, 100\%). Imperatives indicate the power which they exercise in such gatherings; i.e. in the presence of other females, but not males. Repetition of the former speaker's previous utterance(s) is used by both males and females in same-sex conversations ( 9 times, $53 \%$ of males' total use and 8 times, $66.6 \%$ of females' total use) more than in mixed-sex ones (8 times, $47 \%$ of males' total use and 4 times, $33.4 \%$ of females' total use). This is because when speakers are of the same gender, they are freer in making fun and are being sarcastic of each other in whatever they say or do. Males use cognitive verbs equally in same- and mixed-sex conversations ( 8 times, 50\%). This shows that males have no problems in expressing their attitudes, feelings, and knowledge freely regardless of the gender of other speakers. However, females use them in same-sex conversations 
(14 times, $60.8 \%$ ) more than in mixed-sex ones ( 9 times, $39.2 \%)$. This may be because females in each other's company feel freer to talk about their attitudes, feelings and knowledge. Emphatic stress is used by females only in mixed-sex conversations as they want other speakers, especially males, to listen to what they say, accept it and appreciate it. Tag questions are used by both males and females in same-sex conversations (11 times, $65 \%$ of males' total use and 10 times $55.6 \%$ of females' total use) more than in mixed-sex ones (6 times, $35 \%$ of males' total use and 8 times, $44.4 \%$ of females' total use). This may be because when speakers are of the same gender, they have equal power. Thus, the current speaker wants other participants to respond and agree to what he/she says humorously. Males use pragmatic particles equally in same- and mixed-sex conversations (11 times, 50\%) to express agreement with other speakers' humour. However, females use them in samesex conversations (16 times, $59 \%$ ) more than in mixedsex ones (11 times, $41 \%$ ). This may be because females among each other favour solidarity and agreement more than in the company of males, where there might be challenges between both genders. 


\section{Conclusion}

The study reveals that the mostly used linguistic devices to construct gender identity by males are: imperatives, followed by repetition of the former speaker's previous utterance(s), epistemic "I", decisional "I", tag questions, and pragmatic particles. The least used linguistic device is cognitive verbs. Males do not use emphatic stress to construct their gender identity. However, the most commonly used linguistic devices by females to perform the same function of constructing their gender identity are: emphatic stress, which is only used by females, followed by pragmatic particles, cognitive verbs, pragmatic particles, tag questions, decisional "I", epistemic "I", repetition of the former speaker's previous utterance(s), and imperatives. The study also manifests that the most commonly used linguistic devices by males in same-sex conversations are: tag questions, followed by epistemic "I", imperatives, and repetition of the former speaker's previous utterance(s).The least used devices are decisional "I", cognitive verbs, and pragmatic particles, all of which are equally used. Moreover, the most commonly used linguistic devices by males in mixed-sex conversations are: decisional "I", pragmatic particles, 
and cognitive verbs, all of which are equally used. These are followed by repetition of the former speaker's utterance(s), followed by imperatives and epistemic "I". The least used device is tag questions. Emphatic stress is not used by males at all. Regarding females, the most commonly used linguistic devices in same-sex conversations are: emphatic stress, which is only used in same-sex conversations, followed by repetition of the former speaker's previous utterance(s), cognitive verbs, pragmatic particles, tag questions, and epistemic "I". The least used device is decisional "I". In addition, the most commonly used linguistic devices by females in mixed-sex conversations are: emphatic stress, which is only used by females in mixed-sex conversations, followed by decisional "I", epistemic "I", tag questions, pragmatic particles, and cognitive verbs. The least used linguistic device is repetition.

It can be said that using certain linguistic devices to construct gender identity in the humorous conversations of males and females can be associated with masculine and feminine ways of speaking because of the traditions of the society. For example, epistemic "I is used more by males. This shows that males like to talk about what they know openly in humorous 
conversations more than females. As for decisional "I", it is equally used by both males and females to indicate that both have their own opinions to which they are committed. Regarding imperatives in humorous utterances, they are used more by males due to the power society gives to males. Repetition of the former speaker's previous humorous utterance(s) is used more by males. Males use this device as a source of humour and sarcasm more than females who do not do this as they care about and consider the feelings of other speakers. However, females use it in humour to emphasize what they say, and to make sure that their humorous comments are understood by other participants in the on-going conversation. Cognitive verbs are used more by females because they can be more expressive of what they know. Emphatic stress in humorous utterances is only used by females. This shows that they want other participants to listen to what they say humorously and understand it. Tag questions are used more by females to elicit confirmation to what they say humorously and make other participants accept it due to the uncertainty they might feel. Pragmatic particles are also used more in humorous utterances by females who favour solidarity and 
friendliness in their speech. The fact that females use tag questions and pragmatic particles more than males has been also confirmed by Lakoff (1975). It can be said that gender identity in a given interaction depends on the participants' familiarity with the significance of some linguistic devices.

In same-sex humorous conversations, males try to construct their gender identity by portraying themselves as modern, knowledgeable, superior to other male participants, fashionable, and stylish. They also try to challenge each other's power as well as any humorous comments which can put them on the defensive and destroy their image. They are also aware of the positive self-image other male speakers try to establish for themselves. In fact, they present themselves as having "heroic positions" because they "align themselves strongly with conventional ideals" (Wetherell \& Edley, 1999: 343).This conforms to Holmes (1997: 209-210) who states males in conversations present themselves as competent, skilled, and always in control. Regarding females, they portray themselves as strong, independent, hard working, and capable of carrying out big missions and responsibilities. In addition, they need each other's 
moral and spiritual support. Females also challenge whatever puts them on the defensive as well as men's traditional views about them.

In mixed-sex humorous conversations, females present themselves as knowledgeable and chic, while males, sometimes, try to be sarcastic of them. Males also sometimes try to underestimate what females say to keep the traditional view about the superiority of males to maintain a positive self-image. However, females sometimes challenge this sarcasm and underestimation humorously to resist any negative views in society regarding them, and thus keep their positive self-image.

It is clear that females in the analysed humorous conversations, whether same-sex or mixed sex, no longer portray themselves as the "good mother", the "caring daughter", or one who can be overwhelmed by events (Crawford, 2003: 1421; Holmes, 1997: 207-209). Rather, they portray themselves positively and as having the same status and prestige as males. Therefore, they resist all kinds of social constraints. Males in their humour generally look for status (Crawford, 1995: 68).

It can be said that in the modern age, women are no longer powerless or on the defensive. Because they 
have succeeded in obtaining their social, political, and economic rights, they now have the same power as males. As a result, there is an increasing refusal of antifemale humour, and acceptance of humour that challenges males' traditional views regarding females (Crawford, 2003:1425). Thus, males' traditional views concerning females are now changing, and women are acquiring new roles and status in modern societies. 
Transcription Conventions

[Overlapped speech

( ) A number between brackets is the number of repetition of the previous word.

Emphatically stressed lexical items are written in capital letters 


\section{References}

Aries, E. (1982). Verbal and Nonverbal Behavior in Single-sex and Mixed-sex Groups: Are Traditional Sex Roles Changing? Psychological Reports (51): 127-134.

Brown, P. (1993). Gender, Politeness, and Confrontation in Tenejapa. In Deborah Tannen (Ed.), Gender and Conversational Interaction. Oxford, OUP.

Brown, P. \& Levinson, S. C. (2004). Politeness: Some Universals in Language Usage. In Adam Jaworski and Nikolas Coupland (Eds.), The Discourse Reader (pp. 324-35). New York: Routledge.

Cameron, D. (1995). Rethinking Language and Gender Studies: Some Issues for the 1990s. In Sarah Mills (Ed.) Language and Gender: Interdisciplinary Perspectives. London: Longman.

Coates, J. (1989). Gossip Revisited: Language in All-female Groups. In J. Coates \& D. Cameron (Eds.), Women in their Speech Communities, pp. 29-121. London: Longman.

Coates, J. (1993). Women, Men and language. Essex: Longman. 
Coates, J. (1996). Women Talk: Conversation between Women Friends. Oxford: Blackwell Publishers.

Crawford, M. (1995). Women Talk. Oxford: Blackwell.

Crawford, M. (2003). Gender and Humor in social Contexts. Journal of Pragmatics (35)1413-1430.

Davenport, M.K. \& Hannahs, S.J. (1998). Introducing Phonetics and Phonology. London: Hodder Education.

Eckert, P. (1989). The Whole Woman: Sex and Gender Differences in Variation. Language Variation and Change (1):245-267.

Ervin-Tripp, S. \& Lampert, M.D. (1997). Gender Differences in the Construction of Humorous Taljk. In Kir Hall et al. (Eds.), Locating Power. Proceedings of the second Berkeley Women \& Language Conference, April $4^{\text {th }} \& 5^{\text {th }} 1992$, Berkeley Women and Language Group, Berkeley, CA, Vol. 1, pp.108-117.

Fasulo, A.\& Zucchermaglio, C. (2002). My Selves and I: Identity Markers in Work Meeting Talk. Journal of Pragmatics (34): 1119-1144. 
Ferreira, D. M.M. (2003). Culture \& Society: The Identity of the Feminine Manifestation. Journal of Language and Linguistics, vol. (2), 47-55.

Goffman, E. (1963). Behaviour in Public Places. New York: Free Press.

Goodwin, M.H. (1990). He-Said-She-Said: Talk as Social Organization among Black Children. Bloomington: Indiana University Press.

Halliday, M.A.K. (1994). An Introduction to Functional Grammar. London: Edward Arnold.

Hay, J. (2000). Functions of Humor in the Conversations of Men and Women. Journal of Pragmatics (32), 709-742.

Heritage, J \& Drew, P. (Eds.) (1992). Talk at Work: Interaction in Institutional Settings. Cambridge: CUP.

Holmes, J. (1997). Women, Language, and Identity. Journal of Sociolinguistics (12), 195-223, Oxford: Blackwell Publishers.

Holmes, J. (2000). Politeness, Power \& Provocation: How Humour Functions in the Workplace. Discourse \& Society (2) 159-185. 
Holmes, J. (2006). Sharing a Laugh: Pragmatic Aspects of Humor and Gender in the Workplace. Journal of Pragmatics (38), 26-50.

Holmes, J. \& Marra, M. (2002). Having a Laugh at Work: How Humour Contributes to Workplace Culture. Journal of Pragmatics (34), 1683-1710.

Hopper, R. \& LeBaron, C. (1998). How Gender Creeps into Talk. Research on Language and Social Interaction 31 (3):59-74.

Jenkins, M. (1985). What's so Funny? Joking among Women. In Bremner S. \& Moonwoman, B. (Eds.). Proceedings of the First Berkeley Women in Language Conference, Berkeley, CA, pp. 135-151.

Kotthoff, H. (2006). Gender and Humor: The State of the Art. Journal of Pragmatics (38) 4-25.

Keltner, D., Capps, L., Kring, A.M., Young, R.C., \& Heerey, E. (2001). Just Teasing: A Conceptual Analysis and Empirical Review. Psychological Bulletin (127), 1231-1247.

Lakoff, R. T. (1975). Language and Women's Place. New York: Harper \& Row. 
Lakoff, R. T. (1990). Talking Power: The Politics of Language in our Lives. New York: Basic Books.

Lanehart, S.L. (1996). The Language of Identity. Journal of English Linguistics (24): 322-321.

Lampert, M.D. \& Ervin-Tripp, S.M. (2006). Risky Laughter: Teasing and Self-directed Joking among Male and Female Friends. Journal of Pragmatics 51-72.

Mehl. M.R. \& Pennebaker, J.W. (2003). The Sounds of Social Life: A Psychological Analysis of Students' Daily Social Environments and Nature of Conversations. Journal of Personality and Social Psychology (84): 857-870.

Mulac, A. , Studley, L.B., \& Blau, S (1990). The Gender-linked Effect in Primary and Secondary Student's Improptu Essays. Sex Roles (23): 439-470.

Mulac, A., Bradac, J.J., \& Gibbons, P. (2001). Empirical Support for the Gender-as- culture Hypothesis: An Intercultural Analysis of Male/Female Language Differences. Human Communication Research (27): 121-152.

Mulkay, M. (1988). On Humor: Its Nature and its Place in Modern Society. Oxford: Blackwell Publishers. 
O'Barr, W. \& Atkins, B.K. (1980). Women's Language or "Powerless Language". In McConnellGinet et al (Eds.), Women and Language in Literature and Society, pp. 93-110. New York: Praeger.

Ochs, E. (1992). Indexing Gender. In Alessandro Duranti and Charles Goodwin (eds.), Rethinking Context: Language as an Interactive Phenomenon. Cambridge: CUP.

Ohara,Y. \& Saft, S. (2003). Using Conversation Analysis to Track Gender Ideologies: Toward a Feminist Analysis of a Japanese Phone-in Consultation TV Program. Discourse and Society (14): 153-172.

Richards, J., Platt, J., Platt, H. (1996). Longman Dictionary of Language Teaching and Applied Linguistics. Essex: Longman.

Rogerson-Revell, P. (2007). Humour in Business: A Double-edged Sword. A Study of Humour and Style Shifting in intercultural Business Meeting. Journal of Pragmatics (39) 4-28.

Rutherford, J. (1988). What's that Man? In D. Chapman \& J. Rutherford (Eds.), Males' Order: Unwrapping Masculinity. London: Lawence \& Wishart. 
Sacks, H. (1992). Lectures on Conversation, vol. 1. Blackwell: Oxford.

Schegloff, E.A (1992). In Another Context. In A. Duranti \& C. Goodwin (Eds.), Rethinking Context: Language as an Interactive Phenomenon. Cambridge: CUP.

Tannen, D. (1987). Repetition in Conversation: Toward a Poetics of Talk. Language 63(3): 574-605.

Tannen, D. (1989). Talking Voices: Repetition, Dialogue, and Imagery in Conversational Discourse. Cambridge: CUP.

Tannen, D. (1993). The Relativity of Linguistic Strategies: Rethinking Power and Solidarity in Gender and Dominance. In D. Tannen (Ed.), Gender and Conversational Interaction. Oxford: OUP.

Tannen, D. (1996). Gender and Discourse: Featuring a New Essay on Talk at Work. New York: OUP

Tracy, K. (1998). Analysing Context: Framing the Discussion. Research in language and Social Interaction 31(1)1:-28. 
Weatherall, A. (2000). Gender Relevance in TalkIn-Interaction and Discourse. Discourse \& Society 11(2): 286-288.

Wethrell, M. \& Edley, N. (1999). Negotiating Hegemonic Masculinity: Imaginary Positions and Psycho-discursive Practices. Feminism and Psychology (9): 335-356.

Wehmeier, S. et al. (2005). Oxford Advanced Learners' Dictionary of Current English ( $7^{\text {th }}$ edition). Oxford: OUP.

West, C. (1990). Not just Doctor's Orders: Directiveresponse Sequences in Patient's Visits to Women and Men Physicians. Discourse \& Society (1):85-112.

Wickberg, D. (1998). The Senses of Humor: Self and Laughter in Modern America. Ithaca, NY: Cornell University Press.

Yamaguchi, H. (1988). How to Pull Strings with Words: Deceptive Violations in the Garden Path. Journal of Pragmatics (12): 323-337.

Yus, F. (2003). Humor and the Search for Relevance. Journal of Pragmatics (35): 1295-1331. 
Zajdman, A. (1995). Humorous Face-threatening Acts: Humor as Strategy. Journal of Pragmatics (23) 325-339. 